\title{
Studies on the Effect of Planting Dates and Levels of Pinching on Growth, Flowering and Yield in Marigold (Tagetes erecta) cv. Arka Agni
}

\author{
K. Jyothi ${ }^{1 *}$, CH. Raja Goud ${ }^{1}$, A. Girwani ${ }^{2}$ and T. Suresh Kumar ${ }^{3}$
}

${ }^{1}$ College of Horticulture, SKLTSHU, Rajendranagar, Hyderabad-500030 Telangana, India

${ }^{2}$ College of Horticulture, SKLTSHU, Mojerla, Telangana, India

${ }^{3}$ Horticulture Research Station, Kondamallepally, Nalgonda, Telangana, India

*Corresponding author

\section{A B S T R A C T}

\begin{tabular}{|c|}
\hline Keywords \\
\hline $\begin{array}{l}\text { Marigold, Pinching, } \\
\text { Planting dates, Growth, } \\
\text { Flowering, Yield }\end{array}$ \\
\hline Article Info \\
\hline $\begin{array}{l}\text { Accepted: } \\
22 \text { October } 2018 \\
\text { Available Online: } \\
10 \text { November } 2018\end{array}$ \\
\hline
\end{tabular}

An field experiment was conducted to study the effect of planting dates and pinching levels on growth, flowering in African marigold cv. Arkaagni under open condition. The experiment was laid out with twelve treatment combinations at College of Horticulture, Rajendranagar, Hyderabad during 2017 - 2018, with four planting dates and three levels of pinching. $2^{\text {nd }}$ fortnight of October planting resulted in more plant spread, primary and secondary branches per plant and also increased several floral characters like flower diameter, number and weight of flowers per plant and yield per hectare. Shoot pinching at 32 days after planting improved plant spread, number of leaves, as well as weight of flowers per plant, diameter, number of flowers per plant and yield of flowers per hectare. Interaction effect of $2^{\text {nd }}$ fortnight of October planting with double pinching was found beneficial in improving flower yield per hectare

\section{Introduction}

Marigold is one of the most important commercial flower crops grown world over, accounting for more than half of the nations in loose flower production. It has gained popularity due to easy cultural practices, wide adaptability, profuse flowering, short juvenility, large blooming period, relatively problem free nature, attractive colors, shape, size and good keeping quality. The area under commercial cultivation in India is on the rise owing to its multipurpose use. Flowers are widely used for making garlands, floral decoration, flower baskets, religious offerings, bedding and potting and also for making different products (Swaroop et al., 2007). It is suitable for pigment extraction, natural colourant preparation oil extraction and other value addition products etc., which can help the farmers for maximizing their farm income.

Though, quality of flower and yield is primarily a genotypic trait, it is greatly influenced by the prevailing environment during its growth period. Among other cultural requirements for proper growth and flowering of marigold, planting date is the most important factor which ensures the flower yield and its quality. Flower yield is mainly dependent on number of flower bearing branches which can be manipulated by 
arresting the vertical growth of plants and encouraging side shoots by means of apical bud pinching. Such side shoots would provide more scope to bear flowers and in turn contribute for higher flower yield. The demand for marigold exists throughout the year for various religious and social functions. So, for maximizing yield proper time of cultivation and stage of pinching is necessary.

\section{Materials and Methods}

The experiment was conducted during rabi 2017 - 18 to study the effect of dates of planting and different levels of pinching in marigold cv. Arkaagniat student farm, College of Horticulture, Rajendranagar, SKLTSHU, Hyderabad.

The experiment was laid out by adopting factorial experiment in randomized block design with two factors. The land was brought to a fine tilth by repeated ploughing and harrowing. All the weeds and stubbles of previous crop were completely removed. The spacing was $60 \mathrm{~cm} \times 40 \mathrm{cmwas}$ maintained and all the agronomic package of practices along with plant protection measures was followed.

There were four different dates of planting i.e., $D_{1}-2^{\text {nd }}$ fortnight of September, $D_{2}-1^{\text {st }}$ fortnight of October, $D_{3}-2^{\text {nd }}$ fortnight of October, $D_{4}-1^{\text {st }}$ fortnight of November. Three levels of pinching corresponding to each date of planting. $P_{0}-$ No pinching, $P_{1}-$ Single pinching at 20 DAT, $\mathrm{P}_{2}-$ Double pinching at 12 days after 1 st pinching. The observations were recorded on five randomly selected plants per treatments and replication.

\section{Results and Discussion}

The data pertaining to the vegetative growth and flowering characters of marigold cv. Arkaagni are presented in Tables 1 and 2 respectively.

\section{Effect on growth characters}

Plant height was maximum under $D_{1} 2^{\text {nd }}$ fortnight of September planting $(53.65 \mathrm{~cm})$ closely followed by $\mathrm{D}_{3} \quad\left(2^{\text {nd }}\right.$ fortnight of October) planting $(50.61 \mathrm{~cm})$. The increase in plant height with September planting might be due to prevailing of congenial environmental conditions such as photoperiod and temperature for growth of Marigold. Similar results were reported by Yadram et al., (2015) in African marigold and Prasad and Reddy (2003) in China aster. Tallest plant observed in no pinching $\mathrm{P}_{0}(52.94 \mathrm{~cm})$ and minimum plant height of $(46.72 \mathrm{~cm})$ was noticed with $\mathrm{P}_{2}$ (Double pinching) which is in conformity with the result of Singh and Arora (1980) in marigold and Sehrawat et al., (2003) in marigold.

The maximum number of primary and secondary branches are $\mathrm{D}_{3} 2^{\text {nd }}$ fortnight of October planting (9.12 and 14.09) respectively. While $\mathrm{D}_{4} \quad\left(1^{\text {st }}\right.$ fortnight of November) recorded the minimum (7.26 and 9.82) respectively. Similar results were reported by Jane et al., (2001) in chrysanthemum and Hazarika et al., (2003) in African marigold. The data on number of primary branches and secondary branches per plant were found to be significantly influenced by different pinching levels. The maximum Number of primary and secondary branches was noticed in $\mathrm{P}_{2} \quad(8.98$ and 13.93) respectively. As the apical dominance is removed the plant itself usually adjusts to encourage the growth of auxiliary buds which may be converted to branches. Similar results were also found by Habiba (2012) in different flowering plants. Plant spread (N-S and E-S) was maximum in $\mathrm{D}_{3}$ ( $2^{\text {nd }}$ fortnight of October) planting $(37.62 \mathrm{~cm}, 36.55 \mathrm{~cm})$ and minimum was recorded in $\mathrm{D}_{4} \quad\left(1^{\mathrm{st}}\right.$ fortnight of November) $(31.67 \mathrm{~cm}, 31.17 \mathrm{~cm})$ respectively. This might be due increase in number of primary and secondary branches per plant. 
The results are in conformity with the findings of Lakshmi et al., (2014) in African marigold. Pinching had significant effect on plant spread in $\mathrm{E}-\mathrm{W}$ and $\mathrm{N}-\mathrm{S}$ direction. Among different pinching treatments, $\mathrm{P}_{2}$ (Double pinching) at 32 DAT recorded significantly highest plant spread $(37.69 \mathrm{~cm}$ and $36.68 \mathrm{~cm})$ and minimum in single pinching $(31.42 \mathrm{~cm}$ and $31.39 \mathrm{~cm})$ respectively. Similar results were also recorded by Maharnor et al., (2011) in marigold and Mohanty et al., (2015) in African marigold.

The data recorded on growth parameters presented in Table 2 revealed that various combinations of planting time and pinching $\mathrm{D}_{1} \mathrm{P}_{0}$ ( $2^{\text {nd }}$ fortnight of September + No pinching) recorded the highest plant height of $(57.88 \mathrm{~cm})$ and minimum was recorded in $\mathrm{D}_{4} \mathrm{P}_{2}$ (1st fortnight of November + Double pinching) $(41.18 \mathrm{~cm})$ whereas plant spread in both direction (E-W and $\mathrm{N}-\mathrm{S}) \mathrm{D}_{3} \mathrm{P}_{2}\left(2^{\text {nd }}\right.$ fortnight of October + Double pinching) treatment combination was maximum (38.40 $\mathrm{cm}, 39.13 \mathrm{~cm}$ ) respectively. However, plant spread of various combinations could not bring any significant change.

\section{Effect on floral characters}

The data recorded on floral parameters presented in Table 1 revealed planting time had significant influence on the number of days taken to $50 \%$ flower bud appearance $\mathrm{D}_{4}$ $\left(1^{\text {st }}\right.$ fortnight of November) planting recorded significantly highest number of days (46.71days) followed by the $\mathrm{D}_{1}\left(2^{\text {nd }}\right.$ fortnight of September) minimum number of days observed in $\mathrm{D}_{3}$ (40.71 days). These results are in conformation with the findings Samantaray et al., (1999) in marigold. Among different pinching levels, $\mathrm{P}_{2}$ (Double pinching) recorded significantly highest number of days. The lowest number of days to first flowering was observed in $\mathrm{P}_{0}$ (39.54 days). By removal of apical portion, the plants continued the vegetative phase and the new shoots which emerged on the pinched plants took longer time for physiologically mature and flower bud initiation. These results are in close conformity with earlier reports of Sehrawat et al., (2003) and Beniwal et al., (2003) in marigold, Srivastava et al., (2005) in marigold.

Maximum number of days taken for $50 \%$ flower opening was $\mathrm{D}_{4}$ (65.96 days)and minimum days (56.83 days) observed in $\mathrm{D}_{3}$ ( $2^{\text {nd }}$ fortnight of October). This results were conformity with the findings of Lakshmi et al., (2014) in marigold and Sharma et al., (2015) in Gaillardia.

The maximum delay in $50 \%$ flowering was noticed in the treatment (Double pinching) $\mathrm{P}_{2}$ (65.38 days), and minimum number of days observed in $\mathrm{P}_{0}$ (57.31 days). Pinching helps in altering the source-sink relationship thereby advancing the reproductive phase. These results are in close conformity with earlier reports Grawal et al., (2004) in chrysanthemum, Srivastava et al., (2005) in marigold

Flowering duration had showed a significant effect of which maximum number of days (52.07days) taken for flowering is $\mathrm{D}_{3}\left(2^{\text {nd }}\right.$ fortnight of October) and the lowest number of days (39.86 days) observed in $\mathrm{D}_{4}\left(1^{\text {st }}\right.$ fortnight of November) planting. Lakshmi et al., (2014) in African marigold and Sharma et al., (2015) in gaillardia, Samantaray et al., (1999) in African marigold. The maximum days taken for flowering duration was noticed in double pinching $\mathrm{P}_{2}$ (50.48 days) plants, which was followed by single pinching $\mathrm{P}_{1}$ (47.60 days) and minimum number of days taken for flowering duration is $\mathrm{P}_{0}$ (42.14 days) unpinched plants. Similar results were supported by Srivastava et al., (2002) in marigold and Khandelwal et al., (2003) in marigold. 


\section{Int.J.Curr.Microbiol.App.Sci (2018) 7(11): 2705-2713}

Table.1 Effect of planting dates and Pinching on growth and flowering characters

\begin{tabular}{|c|c|c|c|c|c|c|c|c|c|c|c|c|c|c|}
\hline Treatments & $\begin{array}{l}\text { Plant } \\
\text { height }\end{array}$ & \multicolumn{2}{|c|}{ Plant spread } & \multicolumn{2}{|c|}{ No. of branches } & $\begin{array}{l}\text { No. of days } \\
\text { taken to } \\
50 \% \text { flower } \\
\text { bud } \\
\text { appearance }\end{array}$ & $\begin{array}{l}\text { No. of } \\
\text { days to } \\
50 \% \\
\text { flower } \\
\text { opening }\end{array}$ & $\begin{array}{l}\text { Flowering } \\
\text { duration }\end{array}$ & $\begin{array}{l}\text { No. of } \\
\text { flowers } \\
\text { per } \\
\text { plant }\end{array}$ & $\begin{array}{l}\text { Wt of } \\
\text { flowers } \\
\text { /plant } \\
\text { (gm) }\end{array}$ & $\begin{array}{l}\text { Flower } \\
\text { diamete } \\
\text { r (cm) }\end{array}$ & $\begin{array}{l}\text { Average } \\
\text { flower wt } \\
\text { (gm) }\end{array}$ & $\begin{array}{l}\text { Total } \\
\text { plot } \\
\text { yield } \\
(\mathrm{kg})\end{array}$ & $\begin{array}{l}\text { Yield / } \\
\text { hectare } \\
(\mathrm{t})\end{array}$ \\
\hline $\begin{array}{ll}\text { Dates of } \\
\text { planting }\end{array}$ & & $\mathrm{E}-\mathrm{W}$ & $\mathrm{N}-\mathrm{S}$ & $\begin{array}{l}\text { Primar } \\
\mathrm{y}\end{array}$ & $\begin{array}{l}\text { Secondar } \\
\mathrm{y}\end{array}$ & & & & & & & & & \\
\hline $\mathrm{D}_{1}$ & 53.21 & 32.96 & 33.27 & 8.00 & 11.67 & 44.01 & 62.77 & 44.65 & 45.64 & 336.85 & 6.20 & 7.54 & 8.38 & 13.41 \\
\hline $\mathbf{D}_{2}$ & 48.23 & 36.23 & 35.25 & 8.63 & 12.82 & 42.03 & 60.26 & 50.39 & 48.35 & 389.94 & 6.29 & 8.07 & 9.72 & 15.54 \\
\hline $\mathbf{D}_{3}$ & 50.61 & 37.62 & 36.55 & 9.12 & 14.09 & 40.71 & 56.83 & 52.07 & 50.51 & 417.77 & 6.88 & 8.29 & 10.43 & 16.69 \\
\hline $\mathrm{D}_{4}$ & 47.60 & 31.17 & 31.67 & 7.62 & 9.82 & 46.71 & 65.96 & 39.86 & 44.30 & 313.52 & 5.11 & 7.29 & 7.74 & 12.38 \\
\hline S.Em \pm & 0.43 & 0.52 & 0.50 & 0.22 & 0.40 & 0.63 & 0.62 & 0.46 & 0.43 & 4.50 & 0.25 & 0.15 & 0.14 & 0.21 \\
\hline C.D at 5\% & 1.28 & 1.53 & 1.49 & 0.65 & 1.17 & 1.86 & 1.84 & 1.36 & 1.26 & 13.21 & 0.75 & 0.44 & 0.42 & 0.64 \\
\hline Factor 2 & & & & & & & & & & & & & & \\
\hline $\begin{array}{l}\begin{array}{l}\text { Levels of } \\
\text { pinching }\end{array} \\
\end{array}$ & & & & & & & & & & & & & & \\
\hline No pinching & 52.94 & 31.39 & 31.42 & 7.79 & 10.07 & 39.54 & 57.31 & 42.14 & 41.14 & 322.43 & 6.54 & 8.08 & 8.00 & 12.79 \\
\hline $\begin{array}{l}\text { Single } \\
\text { pinching }\end{array}$ & 50.06 & 34.40 & 34.45 & 8.26 & 12.31 & 42.90 & 61.67 & 47.60 & 47.38 & 367.36 & 6.11 & 7.75 & 9.08 & 14.52 \\
\hline $\begin{array}{l}\text { Double } \\
\text { pinching }\end{array}$ & 46.72 & 37.69 & 36.68 & 8.98 & 13.93 & 47.65 & 65.38 & 50.48 & 53.09 & 403.76 & 5.71 & 7.57 & 10.12 & 16.19 \\
\hline S.Em \pm & 0.38 & 0.45 & 0.44 & 0.19 & 0.34 & 0.55 & 0.54 & 0.40 & 0.37 & 3.90 & 0.22 & 0.13 & 0.12 & 0.18 \\
\hline C.D at $5 \%$ & 1.11 & 1.33 & 1.29 & 0.56 & 1.02 & 1.61 & 1.59 & 1.17 & 1.09 & 11.44 & 0.65 & 0.38 & 0.36 & 0.55 \\
\hline
\end{tabular}




\section{Int.J.Curr.Microbiol.App.Sci (2018) 7(11): 2705-2713}

Table.2 Interaction effect of planting dates and levels of pinching on growth and floral characters

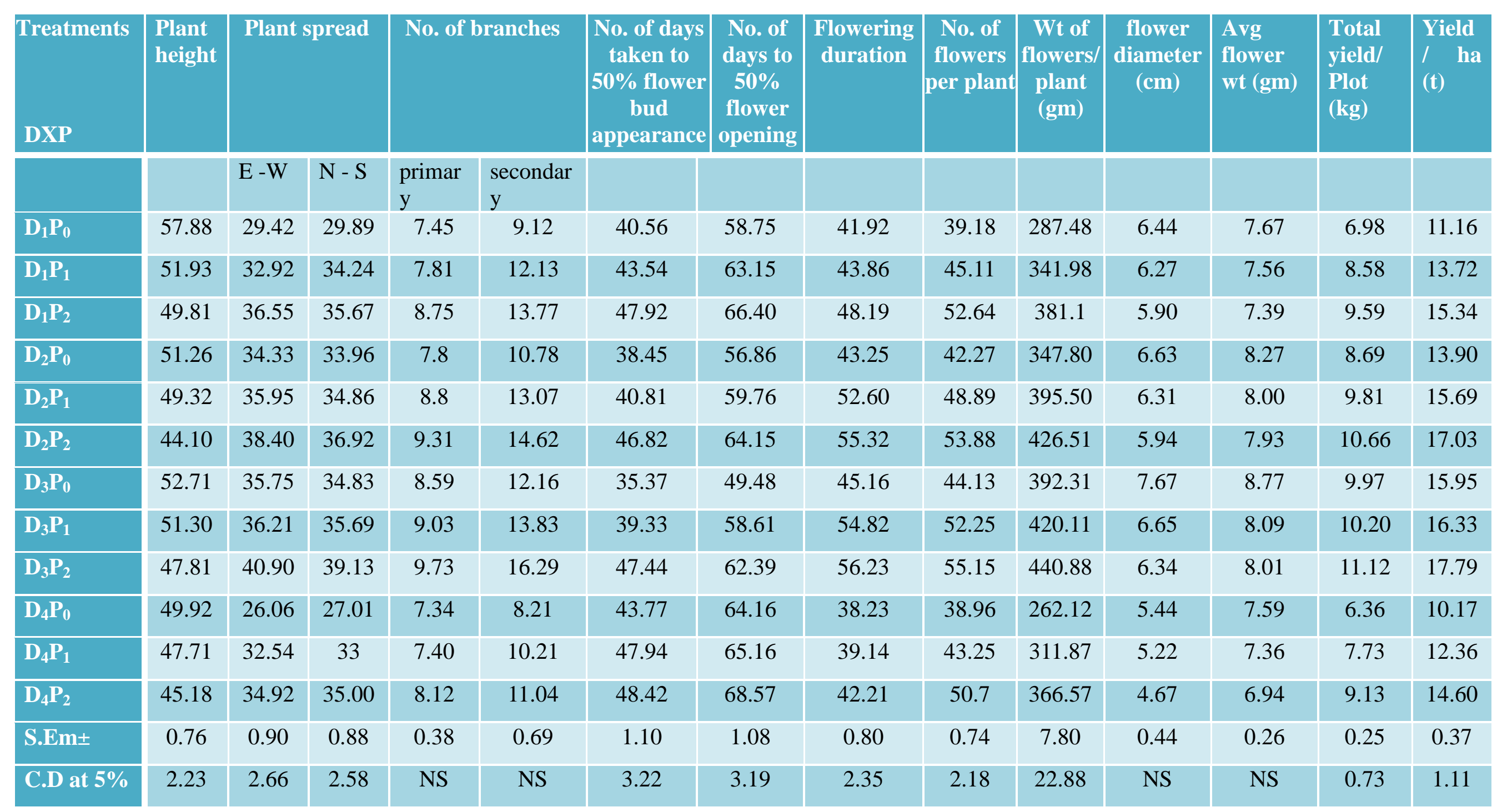


Significantly higher number of flowers (50.51) was recorded in $\mathrm{D}_{3}$ ( $2^{\text {nd }}$ fortnight of October) planting which was followed by $\mathrm{D}_{2}$ $\left(1^{\text {st }}\right.$ fortnight of October) recording (48.35). The results are conformity with findings of Ghosh and pal (2008) in marigold, Smita et al., (2012) in marigold, Lakshmi et al., (2014) in marigold. Double Pinching $\left(\mathrm{P}_{2}\right)$ has possessed significantly more number of flowers per plant (53.09), which was followed by $\left(\mathrm{P}_{1}\right)$ Single pinch at 20 DAT (47.38). The lesser number of flowers per plant (41.14) was recorded in $\left(\mathrm{P}_{0}\right)$ no pinching plants. Increase in number of flowers may be due to the fact that pinched plant induces production of large number of axillaries shoots resulting in well-shaped bushy plants bearing more number of uniform flowers. Similar findings were found by Pushkar and Singh (2012) in marigold, Badge et al., (2014) in marigold and Meena et al., (2015) in marigold.

Maximum weight of flowers per plant (417.77 gm) was observed in $\mathrm{D}_{3}$ ( $2^{\text {nd }}$ fortnight of October) and minimum weight $(313.52 \mathrm{gm})$ of flowers are noticed in $\mathrm{D}_{4}$ planting $\left(1^{\text {st }}\right.$ fortnight of November). Double Pinching $\left(\mathrm{P}_{2}\right)$ has possessed significantly maximum weight of flowers per plant (403.76 gm) and minimum in $\mathrm{P}_{0}(322.4 \mathrm{gm})$. The results are in agreement with the findings of Sreekanth et al., (2006) in marigold and Rajayalakshmi and Rajasekhar (2014) in marigold.

Flower diameter $(6.88 \mathrm{~cm})$ was recorded maximum in $\mathrm{D}_{3}$ ( $2^{\text {nd }}$ fortnight of October) planting and minimum was observed in (5.11 $\mathrm{cm}$ ) has been observed in $\mathrm{D}_{4}\left(1^{\text {st }}\right.$ fortnight of November) planting. Similar results were also reported by Mathad et al., (2008) in China aster and Sharma et al., (2015) in gaillardia. Significantly maximum flower diameter (6.54 $\mathrm{cm})$ was recorded in non- pinched plants $\left(\mathrm{P}_{0}\right)$, which was on par with pinching at 20 DAT $(6.11 \mathrm{~cm})$ Single pinching $\left(\mathrm{P}_{1}\right)$ minimum $(5.71 \mathrm{~cm})$ was recorded at pinching 32 DAT
Double pinching $\left(\mathrm{P}_{2}\right)$. Similar findings were revealed by Sasikumar et al., (2015) in African marigold, Rathore et al., (2011) in marigold.

Total yield per plot was significantly maximum $(10.43 \mathrm{kgs})$ in $\mathrm{D}_{3}\left(2^{\text {nd }}\right.$ fortnight of October) and minimum $(7.74 \mathrm{~kg})$ was recorded in $\mathrm{D}_{4}$ planting $\left(1^{\text {st }}\right.$ fortnight of November). The present findings are in association with the findings of Sreekanth et al., (2006), Anil et al., (2015). Significantly maximum yield of flower per plot (10.12 kgs) was recorded in Double pinching $\left(\mathrm{P}_{2}\right)$, followed by $(9.08 \mathrm{kgs})$ Single pinching $\left(\mathrm{P}_{1}\right)$. The minimum $(8.00 \mathrm{kgs})$ was recorded in Double pinching $\left(\mathrm{P}_{2}\right)$. The similar results are quoted by Pawar (2001) in chrysanthemum, Sharma et al., (2012) in marigold. Significantly higher flower yield (16.69 t/ha), which was followed by $\mathrm{D}_{2}$ planting date $\left(1^{\text {st }}\right.$ fortnight of October) with $15.54 \mathrm{t} / \mathrm{ha}$. The least flower yield per hectare (12.38 t/ha) was recorded in $\mathrm{D}_{4}\left(1^{\text {st }}\right.$ fortnight of November) planting. Double Pinching was the most productive with 16.19 t/ha flower yield followed by Single pinching (14.52 t/ha) whereas, minimum flower yield of $12.79 \mathrm{t} / \mathrm{ha}$ was recorded by $\mathrm{P}_{0}$ non pinched plants. Similar results were also obtained by Sharma et al., (2012) in marigold, and Mohanty et al., (2015) in African marigold.

The data recorded on floral parameters presented in Table 2 revealed that interaction of planting dates with pinching had significant effect. It was observed that significantly more number of flowers per hectare was produced in $2^{\text {nd }}$ fortnight of October planting and double pinching $\mathrm{D}_{3} \mathrm{P}_{2}$ (17.79 t/ha) and minimum flower yield (10.17 t/ha) was recorded in $\mathrm{D}_{4} \mathrm{P}_{0}$ treatment combination. However average weight and flower diameter was found to be had no significant influence on various treatment combination. 
Based on the result of the present study it is concluded that among the four planting dates tried, $2^{\text {nd }}$ fortnight of October planting improved several growth characters like plant spread, number of branches per plant. Also it was beneficial in improving several floral characters like diameter, fresh weight of individual flower, number and weight of flower per plot and yield of flower. Shoot pinching in marigold once at 32 days after planting improved plant spread, primary and secondary branches per plant. Rather, it was effective in bringing significant improvement in number and weight of flower per plot and yield per hectare. Interaction effect of $2^{\text {nd }}$ fortnight of October planting with double pinching at 32 days after planting was found beneficial in flower yield.

Prevalence of congenial atmospheric condition with moderate temperature during $2^{\text {nd }}$ fortnight of October planting coupled with favourable effect of Double pinching in improving the number of branches per plant might have contributed significantly for increased flower number plant and plot under this treatment combination

\section{References}

Anil, K. S, Udit, K and Arun, K. 2015. Effect of planting date and spacing on performance of African marigold (Tagetes erecta Linn) cv. PusaNarangiGainda under North Bihar agro-ecological conditions. International Journal of Forestry and Crop Improvement. 6(1):16-20

Badge, S, Panchbhai, D. M and Dod, V.N. 2014. Response of pinching and foliar application of gibberellic acid on growth and flower yield in summer African marigold. Res. on Crops. 15(2):394-397

Beniwal, B.S, Ahlawat, V.P and Rakesh. 2003. Studies on Effect of spacing and pinching on growth flower production of Chrysanthemum. Haryana journal of Horticulture Science. 32 (3-4): 228-229.

Gosh, P and Pal, P. 2008. Performance of Tagetes erecta Linn. cv. Sirakole as influenced by planting time and spacing under West Bengal conditions. Natural Product Radiance. 7(5):437-443.

Grawal, H. S, Kumar, R and Singh, H. 2004. Effect of nitrogen, planting time in Chrysanthemum cv. Flirt. J. Ornamental Hortic. 7(2):196-199.

Habiba, S.U. (2012). Effect of pinching and foliar application of growth chemicals on growth and flowering of Chrysanthemum. An M. S. thesis, Dept. of Horticulture, Sher-e-Bangla Agricultural University, Dhaka, Bangladesh. 60

Hazarika, K, Preethi, H, Paswan, L and Kalitha, P. 2003. Comparision of dates of planting and growing conditions on growth and flowering of African marigold (Tagetes erecta L.) National Symposium on recent Advances in Indian Floriculture. pp13.

Jane, R.N, Kawarkhe, V. J and Jadhao, B.J. 2001. Effect of different dates of planting on the flower yield of annual chrysanthemum (Chrysanthemum coronarium). Orissa journal of Horticulture. 29(20): 19-22

Khandelwal, S.K, Jain, N. K and Singh, P. 2003. Effect of growth retardants and pinching on growth and yield of African marigold (Tagetes erecta L.). Journal of Ornamental Horticulture. 6(3):271-273

Lakshmi, Rajesh, K, Pandey, Sheetal Dogra, Nomita Laisharm, DeepjiBhat, Arvinder Singh and Shivani Jamwal. 2014. Studies on effect of planting dates and spacing in African marigold (Tagetes erecta L.) Progressive Horticulture 46(1): 149-152.

Maharnor, S.I, Chopde, N, Thakre, S and Raut, P.D. 2011. Effect of nitrogen and 
pinching on growth and yield of African marigold, Asian J. Hort. 6 (1): 43-45.

Mathad, R. C, Vyankarnahal, B. S and Despande, V.K. 2008. Influence of planting dates and picking stages on seed yield and quality in aster (Callistephus chinensis Nee) genotypes. Indian Journal of Agricultural Research. 42(3):224-269

Meena, Y, Sirohi, H.S, Tomar, B. S and Kumar, S. (2015). Effect of planting time, spacing and pinching on growth and seed yield traits in African marigold (Tagetes erecta L.) cv. Pusa Narangi Gainda. Indian J. Agril.Sci. 85(6): $797-$ 801

Mohanty, C.R, Mohanty, A and Parthi, R. 2015. Effect of planting dates and pinching on growth and flowering in African marigold cv. Sirakole. The Asian J. Hort. 10(1): 95-99

Pawar, S.P. (2001). Effect of pinching on growth and flowering in chrysanthemum (Dendranthema indicum) cV. PKV Shubhra. M.Sc. Thesis Dr. PDKV, Akola.

Prasad, G and Reddy, B.S. 2003. Growth and flower yield of China aster as influenced by dates of planting. Haryana. J. Hortic. Sci. 32(2):72-74.

Pushkar, N.C and Singh, A.K. 2012. Effect of pinching and growth retardants on flowering and yield of African marigold (Tagetes erecta L.) cv. PusaNarangiGainda 2(1): 1-4.

Rajyalakshmi, R and Rajashekar, M. 2014. Effect of different growth regulators and pinching on growth and flowering of African marigold (Tagetes erecta L.) cv. Pusa Narangi Gainda in different dates of planting. The Journal of Research ANGRU. 42(1):52-54.

Rathore, I, Mishra, A, Moond, S. K and Bhatnagar, P. 2011. Studies on effect of pinching and plant bio regulators on growth and flowering of marigold
(Tagetes erecta L.).Progressive Horticulture, 43(1): 52-55

Samantaray, D, Mohanty, C. R and Behera, T. K. 1999.Effect of planting time and spacing on growth and flower yield of marigold (Tagates erecta L.) cv. 'African yellow.' Indian Journal of Horticulture. 56(4): 382-385.

Sasikumar, K. V, Baskaran and Abirami, K. 2015. Effect of pinching and growth retardants on growth and flowering in African marigold cv. Pusa Narangi Gainda. J. Horticultural Sci. 10(1): 109111.

Sehrawat, S.K, Dahiya, D. S. Singh, Sukhbir and Rana, G. S. (2003). Effect of nitrogen and pinching on the growth, flowering and yield of marigold (Tagetes erecta L.) cv. African Giant Double Orange. Haryana J. Hort. Sci., 32(1/2): 59-61.

Sen, S. K and Naik, J. 1997.Growth and flowering response of pinching and unpinched chrysanthemum to growth regulators treatments. Indian journal of Horticulture. 34:86-9

Sharma, A. K. Chaudhary, S.V. S and Bhatia, R.S. 2012.Effect of spacing and pinching on regulation of flowering in African marigold (Tagetes erecta Linn.) Progressive Agriculture. 12(2):331-336

Sharma, M.K, Parmar, P.B and Singh, A. 2015.Effect of planting dates and nitrogen on growth, flowering and yield of gaillardia (Gaillardia pulchella Fouger) cv. Double Yellow under south Gujarat climatic conditions. International journal of Botany and Research. 5(4):1-6.

Singh, J and Arora, J.S. 1980.Effect of spacing and pinching on growth and flower production of marigold (Tagetes eracta L.). cv. AFRICAN GIANT DOUBLE ORANGE. Proc. National Seminar on production technology for 
commercial flower held at TNAU, Coimbatore. 85-87

Smita, P, Golliwar, V.J, Panchabhai, D. M, Prathana, J and Sonali, D. 2012. Response of African marigold varieties to different planting time on growth and yield under vidarbha conditions (Maharastra). Journal of soils and crops. 22(1):183-187.

Sreekanth, P, Padama, M, Chandrashekar, R. and Madhaulety, T.Y. 2006.Effect of planting time, spacing and Nitrogen levels on flowering of African marigold (Tagetes erecta). Journal of Horticulture. 9(2):97 -101.

Srivastava, S.K, Singh, H.K. and Srivastava, A.K. 2005. Spacing and pinching as factors for regulating flowering in marigold cv. Pusa Basanti Gainda. Haryana Journal of Horticulture Sciences. 34(1-2):75-77.
Swaroop, K, Singh, K. P and Raju, D. V. S. (2007). Vegetative growth, flowering and seed characters of African marigold (Tagetus erecta Linn) as influenced by different growth substances during mild off seasons. J. ornam. Horticulture, 6(2): 134-136

Yadram, M, Sirohi, H. S, Tomar, B. S and Sanjay, K. 2015. Effect of planting time, spacing and pinching on growth and seed yield traits in African marigold (Tagetes erecta) cv. Pusa Narangi Gainda. Indian Journal of Agricultural Sciences. 85(6):797-801

Yassin, G. Md and Pappiah, C.M. (1990). Effect of pinching and manuring on growth and flowering of chrysanthemum CV-MDU-1. South Indian Hort., 38(4): 232-233.

\section{How to cite this article:}

Jyothi, K., CH. Raja Goud, A. Girwani and Suresh Kumar, T. 2018. Studies on the Effect of Planting Dates and Levels of Pinching on Growth, Flowering and Yield in Marigold (Tagetes erecta) cv. Arka Agni. Int.J.Curr.Microbiol.App.Sci. 7(11): 2705-2713.

doi: https://doi.org/10.20546/ijcmas.2018.711.309 